\title{
Macro and microelements, lead, cadmium, functional compounds, antioxidant capacity in fresh, dry cocoa beans and cocoa paste
}

\author{
María E. Tolentino 1,; Pedro Camasca²; Pedro P. Peláez ${ }^{1, ~ * ~(D) ~}$ \\ 1 Universidad Nacional Agraria de la Selva. Facultad de Ingeniería en Industrias Alimentarias. Av. Universitaria Km. \\ 1,5, Leoncio Prado, Tingo María, Huánuco, Perú. \\ 2 Cooperativa Agraria Cafetalera Divisoria Ltda., Caserío Mapresa km. 4.40 C.F.B. Santa Martha, Leoncio Prado, \\ Huánuco, Perú.
}

Received March 31, 2019. Accepted September 8, 2019.

\begin{abstract}
The cocoa bean and its by-products are widely consumed in the world, due to their mineral content, functional compounds and antioxidant capacity, which vary according to how its processed. Fresh dried cocoa beans (FDB), dry fermented beans (FB) and cocoa paste (CP) were investigated, 31 samples in each case. Phosphorus, sodium, calcium, magnesium, copper, iron, zinc, manganese, cadmium lead, total polyphenols, anthocyanins, antioxidant capacity (ABTS, DPPH) expressed in Trolox equivalents (TE) were determined. Principal component analysis (PCA) was used. The mineral analysis established that 12 samples influenced CP1 and CP2. There was more calcium in the M26 sample of FDB, with $3.14 \%$; potassium in the FDB, in M13, with $2.44 \%$. Zinc in the FDB, was found in greater quantity in M30, M22, M23 and M9; with $90.46 \pm 0.19 \mathrm{ppm}$ in M30. Twenty-five samples reached values $\leq 0.61 \pm 0.01 \mathrm{ppm}$ of cadmium. There was a higher lead content in the FDB, in the M20 sample with $3.44 \pm 0.05 \mathrm{ppm}$. The M10 sample, from FDB, presented the highest antioxidant capacity, with values of $591.50 \pm 3.76$ (ABTS) and $513.68 \pm 0.84$ (DPPH) $\mu \mathrm{M}$ TE/g.
\end{abstract}

Keywords: Analysis of main components; minerals; process; cocoa.

\section{Introduction}

Cocoa is sown mainly in West Africa, South America, Asia. Ghana, Indonesia, Nigeria, Brazil, Ecuador, Mexico and Peru, approximately $90 \%$ of world production (IMCO, 2015). The varieties of cocoa grown by the members of the Cooperativa Agraria Cafetalera La Divisoria Ltda., are Criollo, Común, CCN-51, ICS-95, Criollo Morado, among others. The macroelements are minerals that are needed in daily nutritional requirements in the order of grams per day, are $\mathrm{Na}, \mathrm{K}, \mathrm{Cl}, \mathrm{P}, \mathrm{Ca}, \mathrm{Mg}$ and $\mathrm{S}$ (Bakircioglu et al., 2016). Minerals such as $\mathrm{Cu}, \mathrm{Fe}, \mathrm{Mn}$, $\mathrm{Mg}, \mathrm{Se}, \mathrm{Zn}$ are essential for health and play a vital role as a structural part in many enzymes, these minerals are called microelements (Gharibzahedi et al., 2017); These elements are also found in cocoa beans; which finally reach commercial products that are elaborated based on cocoa liquor, and hence influence the nutritional and sensorial quality. There are also heavy metals such as lead and cadmium, which are elements toxic to health, whose presence in cocoa beans reduces their quality (Romero-Estévez et al., 2019; Ovaco and Pineda, 2011). Other compounds such as polyphenols, anthocyanins, theobromine, caffeine, catechins, are also found in cocoa beans. The minerals and compounds listed, have not yet been properly investigated in cocoa beans nor the by-products, which are grown in different geographical areas. The indicated aspects motivated the development of this investigation, its mineral content and its relation with the samples were evaluated; in the same way the content of macroelements such as phosphorus, potassium, sodium, calcium and magnesium; of microelements copper, iron, zinc, manganese; heavy metals cadmium, lead; the content of total polyphenols, 
anthocyanins, antioxidant capacity (DPPH, ABTS), in fresh dry and fermented dry grains and in cocoa paste.

\section{Materials and methods}

\subsection{Place of execution}

The experimental tests were carried out in the laboratories of Food Engineering, Food Analysis, HPLC and Soil Analysis, of the Universidad Nacional Agraria de la Selva. Work was also done at the CAC plant. Divisoria, located at $\mathrm{Km} 4.40$ of the Federico Basadre main road, Santa Marta, Mapresa farmhouse in the Pablo Felipe Luyando district, province of Leoncio Prado, Huánuco region.

\subsection{Samples of cocoa beans}

The cacao trees were georeferenced, selected from 10 parcels, and the cocoa pods were protected with biodegradable bags. The selection of cocoa pods was made considering the production and quality information provided by the farmers, with the support of 2 extension workers from the Cooperativa Agraria Cafetalera la Divisoria. Ltda. Part of the cocoa pods harvested were transferred to the Food Engineering laboratory and the other part was taken to the fermentation center of the cooperative. Part of the dried fermented beans were used for the production of cocoa paste. Figure 1 represents the geographic location of the cocoa samples, considering the sectors: Pumahuasi ( 7 samples), San José de Pucate (3 samples), Mapresa (3 samples), Pendencia (6 Samples), Huayhuantillo (3 samples), Frontera (9 samples).

\subsection{Analysis methods}

Determination of Minerals: It was carried out by absorption spectrophotometry and atomic emission by flame, using the acid wet method of digestion (Barrueta, 2013; Varian, 1989).

Determination of Phosphorus (P): It was carried out by the molybdate method ammonium vanadate, UV-V thermo scientific USA spectrum (Calderón and Pavlova, 2004). Quantification of total polyphenols: it was determined spectrophotometrically according to the Follin-Ciocalteau method (Singleton and Rossi, 1965). Expressed as gallic acid equivalents.

Quantification of anthocyanins: It was determined by the differential $\mathrm{pH}$ method (Martínez et al., 2011).

Determination of Antioxidant Capacity: Ability to inhibit 2,2-diphenyl-1-picrythydrazyl radical (DPPH); was performed by the UV I Visible spectrophotometer method at 510 $\mathrm{nm}$ described by Brand-Williams et al. (1995).

Ability to inhibit free radical 2,2-azinobis (3ethylbenzthiazoline- 6 sulfonic acid) (ABTS ${ }^{\circ}$ + ); was performed by the method described by $\mathrm{Re}$ et al. (1999), The results of the determination of the antioxidant capacity were expressed in Trolox equivalent (ET) described by Miller et al. (1993).

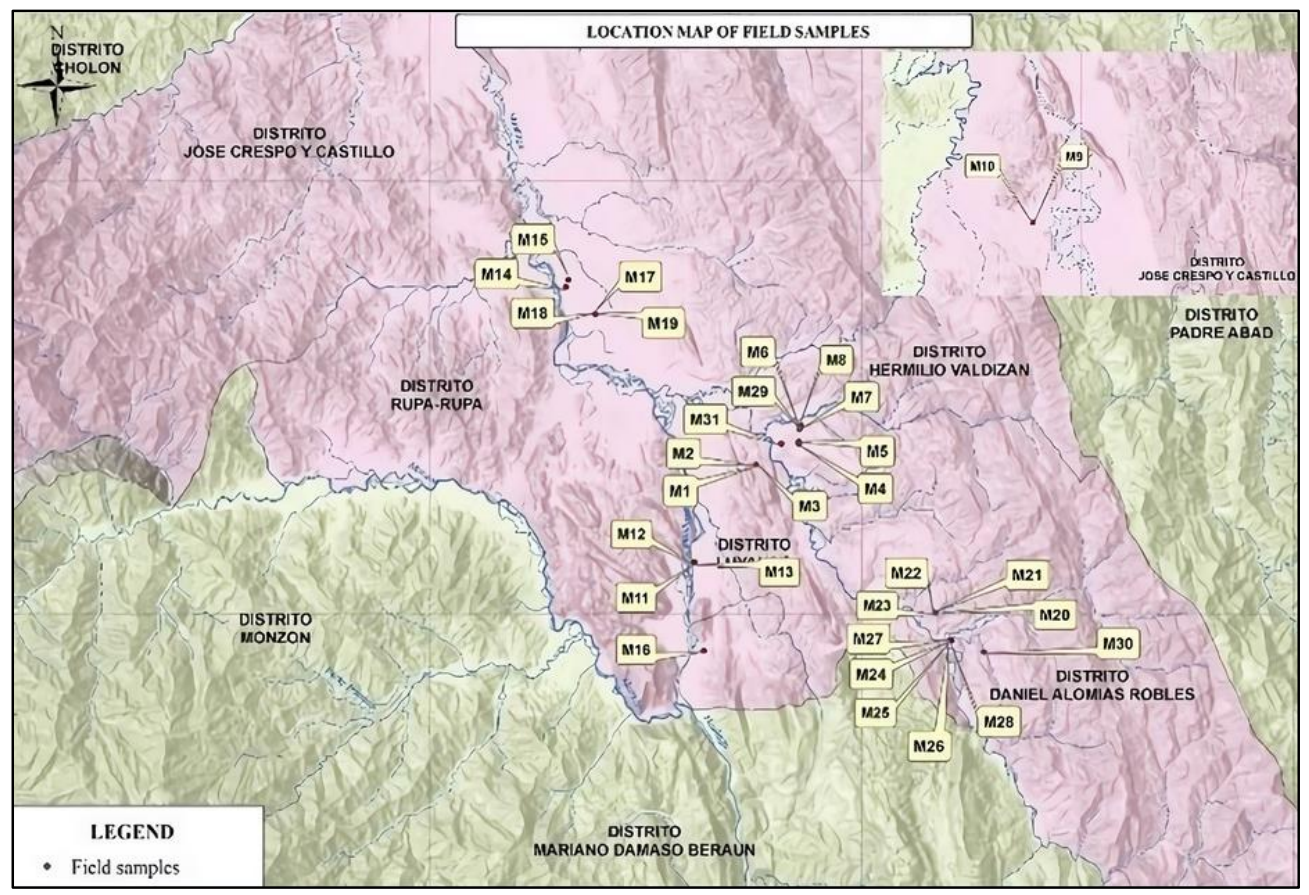

Figure 1. Geographic location of the places where the cocoa samples were taken (Leoncio Prado Province, Huánuco Region, Perú). 


\subsection{Experimental methodology}

In Figure 2, the parameters and procedures for obtaining fresh dry grains, dry fermented grains and cocoa paste are shown, which is described below.

Embossed: this technique served us for a healthy harvest in $90 \%$ of all the sheathed samples; free of more common pests such as: the mazorquero or carmenta, the Phytoptora, Monilia, chinche, etc, (TECNATROP, 2018).

Harvest: The maturity index was taken into account, being duly labeled for each variety of cocoa in each research plot to be later transported to the research centers.

Break and shatter: For this purpose, a dull knife was used and then the seeds were separated from the placenta and placed in nylon meshes duly labeled for each research sample.

Fermentation: The samples were included in the cacao fermentation boxes of the cooperative's normal process, with the removals taking place and controlling 5 days to remove them from the box (APCACAO, 2015).

Drying: Fresh samples were subjected to $60{ }^{\circ} \mathrm{C}$ for 21 hours in the oven while the fermented samples were exposed to the sun on blankets or sacks until obtaining a humidity of $7 \%$ in both cases, according to the NTP (2006).

Roasting: The beans were roasted at $120^{\circ} \mathrm{C}$ for $9 \mathrm{~min}$, in the double-drum toaster, allowing it to cool to room temperature.

Peeling: Done manually separating the husk from the nut.

Grinding: Made manually with the help of a wooden pylon and a stainless-steel bowl since they are small quantities.

Conching: It was subjected to temperatures of $53^{\circ} \mathrm{C}$ for 20 minutes.

Packaging: In the case of fresh dry and fermented samples, it was packed (approximately $400 \mathrm{~g}$ ) in high-density sleeves, coded and sealed, in the case of samples of cocoa paste plastic containers were used (300 grams) approximately), coded and hermetically sealed.

Storage: In the case of fresh dry and fermented samples were stored in cartons at room temperature while samples of cocoa paste were stored at $8^{\circ} \mathrm{C}$, then proceed to obtain the extracts and then perform the chemical analyzes.

Preparation of the extract by acid digestion, wet way for the analysis of macroelements, microelements, cadmium and lead The procedure for the preparation of the extracts was by acid digestion, wet way. It was started once the samples of fresh dry cocoa beans, dry fermented grains and cocoa paste were obtained, then the grinding proceeded, weighing $2 \mathrm{~g}$ of sample. Erlenmeyer flasks previously washed with a solution (1:1) nitric acid with distilled water ( $\mathrm{HNO} 3-\mathrm{H} 2 \mathrm{O}$ d) were used, 5 $\mathrm{ml}$ of the acid mixture 1: $4(4 \mathrm{ml}$ of concentrated nitric acid (HNO3) at $65{ }^{\circ} \mathrm{C}$ was added to each flask). $\%$ and $1 \mathrm{ml}$ of hydrochloric acid (HCL) concentrated to $36.5 \%$. The flasks were then placed in the digestion plates inside the hood of the gas extractor (the acid mixture digested the components of the sample such as proteins, fat, etc.), with the minerals remaining in greater proportion.

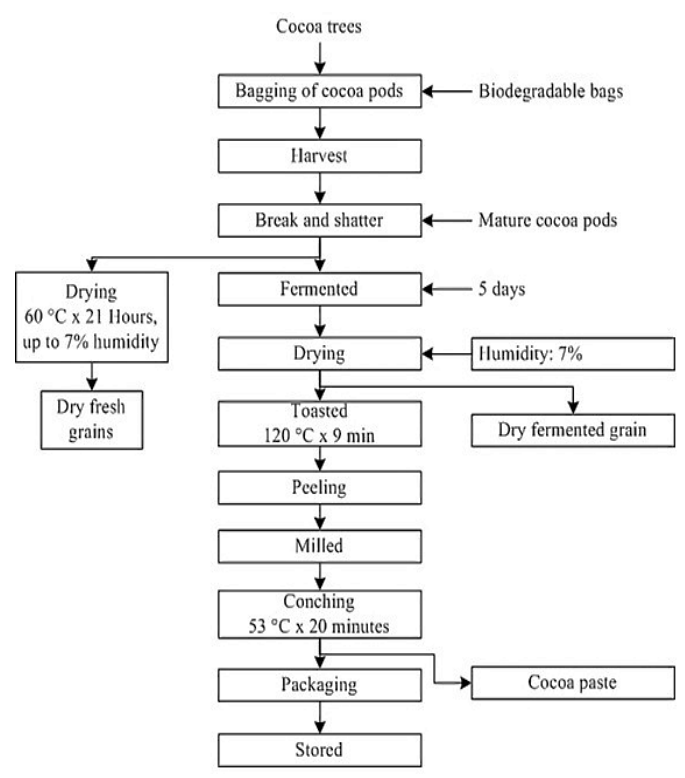

Figure 2. Flowchart for obtaining samples of fresh dry grains, dry fermented grains and cocoa paste.

Then each flask was covered with a funnel, to avoid the volatilization process, the maximum working temperature was $200{ }^{\circ} \mathrm{C}$ for 60 minutes. The digestion ended, when the color was slightly yellow. After that, it was allowed to cool to room temperature without stirring, and $1 \mathrm{ml}$ of hydrogen peroxide ( $\mathrm{H} 2 \mathrm{O} 2$ - hydrogen peroxide) was added, after thirty minutes, it was filtered using filter paper, then it was rooted at 25 $\mathrm{mL}$, in a vial, with distilled water. The filtrate was packed in labeled falcon tubes, aliquots were subsequently taken and the corresponding analysis was performed with the absorption spectrophotometer and atomic emission of flame. $\mathrm{K}, \mathrm{Na}, \mathrm{Ca}, \mathrm{Mg}$, $\mathrm{Cu}, \mathrm{Fe}, \mathrm{Zn}, \mathrm{Mn}, \mathrm{Cd}, \mathrm{Pb}$ were analyzed. The phosphorus $(P)$ were analyzed by visible spectrophotometry, the analysis was carried out in triplicate. 
Preparation of hydroalcoholic extract for the analysis of functional compounds and antioxidant capacity of fresh, dried beans and cocoa mass

The components of the grain samples were extracted with a 50:50 hydroalcoholic solution (V: V), using $20 \mathrm{~mL}$ of solution for each sample, in labeled falcon tubes. The tubes were left stirring for 24 hours at room temperature, then filtered, the obtained extract was filled in Eppendorf tubes, then centrifuged at a temperature of $4^{\circ} \mathrm{C}$, for a time of 10 minutes and at $10000 \mathrm{rpm}$. Then $2 \mathrm{~mL}$ of samples were frozen. Samples were left frozen for later use.

Figure 3 shows the experimental design for the determination of the variable responses (macroelements, microelements, cadmium, lead, functional compounds and antioxidant capacity).

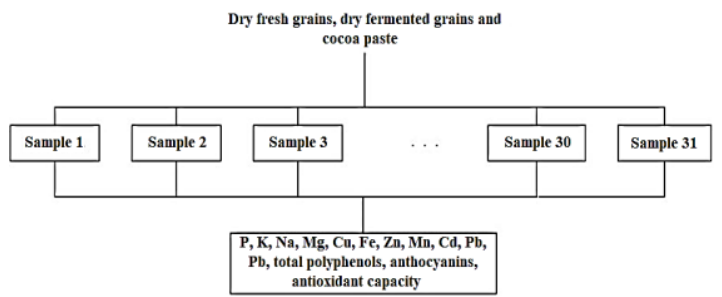

Figure 3. Experimental design to determine the contents of minerals, functional compounds and antioxidant capacity in the samples.

The results of the experimental design shown in Figure 3 were statistically evaluated using the multivariate method of principal component analysis (PCA) (Mesa et al., 2018). Each principal component explains a certain amount of the total information contained in the original data and the first PC contains the largest source of information from the data set. Each subsequent major component contains, in order, less information than the previous one.

In the matrix representation, the model with a given number of components has the following equation: $X=T P T+E$. Where: $T$ is the matrix of scores, $P$ the matrix of charges and $E$ the matrix of errors. The statistical analysis was performed using The Unscrambler ${ }^{\circledR} X$ software, version: 10.4. @2016. CAMO Software AS (Esbensen and Swarbrick, 2017).

\section{Results and discussion}

\subsection{Analysis of mineral contents}

The similarity between dry fresh grains (31 samples), dried fermented grains (31 samples) and their respective pastes (31 samples) were identified, whereby the principal components analysis (PCA) was used. The samples were denominated from
M1 to M31, these were considered independent variables and their mineral contents $\mathrm{P}, \mathrm{K}, \mathrm{Ca}, \mathrm{Mg}, \mathrm{CU}, \mathrm{Fe}, \mathrm{Zn}, \mathrm{Mn}, \mathrm{Cd}$ and $\mathrm{Pb}$, as dependent variables. If the mineral corresponded to dry fresh grain, it was identified as number 1 , if it corresponded to dry fermented grain as 2 and if it corresponded to cocoa paste, as 3; for example, P: P1, P2 and P3; and so forth for each mineral type of each sample respectively. The main advantage of the PCA was the transformation of the correlated variables into new uncorrelated components (orthogonal axes), which transformed making it easier to explain (Bernardo et al., 2018).

Figure 4 shows that the first two main components (PCs) explain $77 \%$ of the variance of the data; $\mathrm{Li}$ et al. (2018) indicated that PCs with percentages close to 100 , will better represent all variables. Clearly three groups of samples were distinguished, two of them were influenced by the calcium content; The group on the right of the $X$ axis had a positive correlation with the calcium content in the dry fresh grains (Ca1), in the dry fermented grains $(\mathrm{Ca} 2)$ and the group of samples on the left of the $X$ axis, had a negative correlation with $\mathrm{Ca} 1$ and $\mathrm{Ca}$. The third group was influenced by the potassium content (K1) in the fresh dry cocoa beans, positively influencing the CP2. It was observed that sample M26 had the highest content of calcium in dry fresh grains with $31,420.8$ ppm and sample M12 had the lowest content, with $12550 \mathrm{ppm}$. The calcium content found in fresh cocoa beans was higher than that reported by (Bertoldi et al., 2016), who found values between 1100 and $1700 \mathrm{ppm}$, in fresh grains, in the same way as reported by (Djikeng et al., 2018), who found $2290 \mathrm{ppm}$ in dry fermented grains; This difference in calcium content can be attributed to various factors, such as soil, climate, variety. The contents of $K$ found were similar to values reported by (Bertoldi et al., 2016), between $1200-14500$ ppm in cocoa beans from different origins of the world and by (Perea et al., 2011), who reported values between $10000-13000$ ppm in Colombian cocoa beans.

The rest of the minerals evaluated had less influence on the variability of responses, which is why they are seen confusingly about the crossing of the axes that form the PCs. The highest content of potassium (K1) was found in the sample M13, in the dry fresh grain, with $24429.2 \mathrm{ppm}$ and the sample M20 presented, the lowest content with 12950 ppm. 


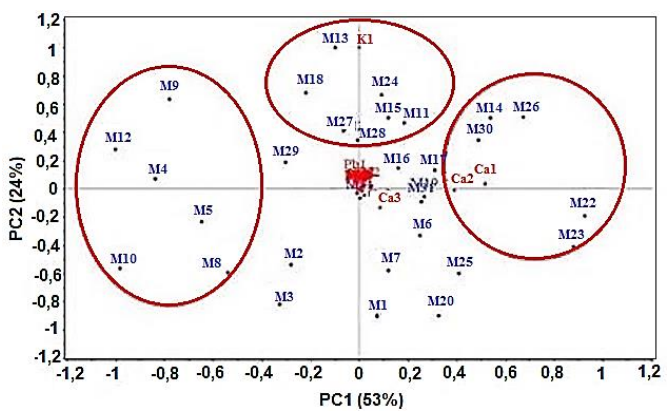

Figure 4. Biplot of PCA, PC1 (53\%) and PC2 (24\%), which explain the relationship between fresh dry grains, fermented dry grains, cocoa paste and mineral content.

The samples that stood out in the variability of responses and influenced the PCAs were 12: M4, M5, M8, M9, M10, M12, M14, M22, M23, M25, M26 and M30 (Mesa et al., 2018), obtained a similar representation when doing an investigation in a fermentation process.

The phosphorus content $(P)$ found varied between $483.24 \pm 23.86-1.975 .54 \pm 13.59$ ppm, corresponding to the sample of fermented dry grain M15, of the $\mathrm{CCN}-5$ variety, of the Pendencia sector and to the sample of cocoa paste from sample M8, VPA-1 from the sector of San José de Pucate. The contents of $P$ found were lower than those reported by (Bertoldi et al., 2016), in the research conducted in samples from the west and east of Africa, Asia, South America and Central America, with values between 4,540 $\pm 38-5,830 \pm 50$ ppm. Also (Perea et al., 2011) reported that $P$ was the most abundant mineral with contents between 1000 - 1300 ppm, in cocoa samples SCC_41, Criollo and FSA_12, in Colombia.

The content of $K$, varied between $1714.58 \pm$ $18.04-29429.17 \pm 36.08 \mathrm{ppm}$, for the sample M2 of dry fermented grain, of the Common variety of the Pumahuasi sector and for the sample M13 of dry fresh grain, variety ICS- 95 of the Mapresa sector, respectively. The contents of $K$ found were different from the one reported by (Bertoldi et al., 2016) in the research carried out on samples of cocoa beans from different parts of the world, with values between $12000 \pm 80-14500 \pm 60 \mathrm{ppm}$, in the same way (Bakircioglu et al., 2016), found in powdered milk samples a value of $12600 \pm$ $40 \mathrm{ppm}$, this content is within the range determined in the cocoa samples.

The content of $\mathrm{Na}$, in the samples of grains and cocoa paste varied between $42.08 \pm$ $0.19-355.75 \pm 5.63 \mathrm{ppm}$, for the samples of fermented dry grain M29, of the CCN-51 variety of the sector of Frontera and dry fresh grain $\mathrm{M} 11$, of the Common variety of the Mapresa sector, respectively. The $\mathrm{Na}$ values determined were similar to those reported by (Bilandzic et al., 2015), for samples of milk, butter, fresh cheese, with contents of $600 \pm 13,110 \pm 26$ and $430 \pm$ 210 ppm, respectively.

The content of $\mathrm{Na}$, in the samples of grains and cocoa paste varied between $42.08 \pm$ $0.19-355.75 \pm 5.63 \mathrm{ppm}$, for the samples of fermented dry grain M29, of the CCN-51 variety of the sector of Frontera and dry fresh grain M11, of the Common variety of the Mapresa sector, respectively. The $\mathrm{Na}$ values determined were similar to those reported by (Bilandzic et al., 2015), for samples of milk, butter, fresh cheese, with contents of $600 \pm 13,110 \pm 26$ and $430 \pm$ 210 ppm, respectively.

3.2. Contents of microelements copper, iron, zinc, manganese in the samples

The copper content $(\mathrm{Cu})$, found in the samples, varied between $29.02 \pm 0.01-4.07$ $\pm 0.05 \mathrm{ppm}$, for the fresh dry grain sample M4, of the Common variety of the Pumahuasi sector and M3 cocoa paste, of the CCN-51 variety of the Pumahuasi sector, respectively. $\mathrm{Cu}$ is an essential trace element in plants and animals. The human body only contains about $150 \mathrm{mg}$ of this vital mineral. The recommended daily dose of $\mathrm{Cu}$ in normal healthy adults is $2 \mathrm{mg} /$ day (Fartusie and Mohssan, 2017). It is necessary for the growth and formation of bones, the formation of myelin sheaths in the nervous systems, helps in the incorporation of $\mathrm{Fe}$ in the hemoglobin, helps in the absorption of $\mathrm{Fe}$ from the gastrointestinal tract and in the transfer of Fe from the tissues to plasma (Studzinski et al., 2006).

The content of $\mathrm{Fe}$, found in the samples varied between $40.51 \pm 0.01-14.46 \pm 0.01$ ppm, the highest content was presented by the dry fresh grain sample M31, of the ICS95 variety of the sector of Frontera and the smaller the dry fermented grain M3, of the CCN-51 variety of the Pumahuasi sector, respectively. It is known that the recommended daily dose of $\mathrm{Fe}$ in normal healthy adults is $8 \mathrm{mg} /$ day for men and postmenopausal women and $18 \mathrm{mg} /$ day for menstruating women (Fartusie and Mohssan, 2017), the Fe contents found in the grains of cocoa, would be easily covering these requirements. Fe's content was reported between 183 - $65.5 \mathrm{ppm}$ in cocoa beans and derivatives (Bertoldi et al., 2016).

The content of $\mathrm{Zn}$, found in the samples varied between $90.46 \pm 0.19-20.75 \pm 0.25$ ppm, the highest content was presented by 
the fresh dry grain sample M30, Common variety of the Frontera sector and the lowest dry fermented grain M18, of the CCN-51 variety of the Pendencia sector, respectively. The recommended daily amount established for $\mathrm{Zn}$ is $\mathbf{8} \mathbf{~ m g} /$ day for women and $11 \mathrm{mg} /$ day for men, the samples showed a higher $\mathrm{Zn}$ content, enough to cover the requirements. It has been reported that $\mathrm{Zn}$ was found between 39.4 - $73.4 \mathrm{ppm}$ in samples of cocoa beans and derivatives (Bertoldi et al., 2016), a range similar to that found in the samples.

The content of manganese $(\mathrm{Mn})$ varied between $33.04 \pm 0.10-3.78 \mathrm{ppm}$, the highest content was presented by fresh dry grain, sample M15, variety $\mathrm{CCN}-51$ of the Pendent sector and the lowest content was presented by the dry fermented grain, shows M11, common variety of the Mapresa sector, respectively. Mn helps the body to form connective tissue, bones, blood clotting factors and sex hormones. In addition, $\mathrm{Mn}$ is a key component of enzyme systems, including enzymes that handle oxygen. The recommended daily dose of $\mathrm{Mn}$ is $2.3 \mathrm{mg} /$ day for adult men and $1.8 \mathrm{mg} \mathrm{/}$ day for adult women (Fartusie and Mohssan, 2017). Mn content was reported for cocoa beans and derivatives between 24.1 - 35.4 (Bertoldi et al., 2016), values similar to those found.

Figure 5 explains the PCA $(96 \%)$, the content of microelements and their correlation with the samples; it can be clearly seen that the highest content is $\mathrm{Zn1}$ in the fresh dry samples M30, M22, M23 and M9 and the lowest in samples M25, M14 and M4; it is also observed that the content of manganese $(\mathrm{Mn} 3)$ is higher in the samples of cocoa paste and in the indicated samples, then decreased for fresh dry samples and dry fermented samples. The presence of copper in the dried fermented samples and in cocoa paste were slightly different. The figure also indicates that iron was present in a smaller amount in sample M25, and increased in samples M14, M4, M8 and M10.

\subsection{Contents of cadmium and lead}

Considering all the samples, the lowest content of cadmium (Cd) was found in the sample of cocoa mass M27, of the CCN-51 variety of the Frontera sector with $0.05 \mathrm{ppm}$ and the highest content in the dry fresh grain sample M17, of the Common variety of the Pendencia sector with $1.20 \pm 0.02 \mathrm{ppm}$. Reglamento (EU) No 488/2014 (Reglamento (EU), 2014), establishes a maximum cadmium content of $0.8 \mathrm{ppm}$ for chocolate with a total dry matter content of cocoa $\geq$
$50 \%$, as of January of the year 2019. None of the indicated samples exceeds this limit, including samples M31, M30, M10, M11 up to $\mathrm{M} 3$ with a maximum cadmium content of $0.61 \pm 0.01 \mathrm{ppm}$; (Bertoldi et al., 2016) reaching 25 samples out of 31 ., they have reported cadmium content in cocoa beans and products between 0.0926 to $1.388 \mathrm{ppm}$ and between 0.17 to 2.16 ppm; (Lewis et al., 2018), also indicated that cadmium (Cd) is a non-essential heavy metal that is toxic to both plants and animals. In humans, exposure to $\mathrm{Cd}$ has been linked to kidney dysfunction, osteoporosis and several types of cancer.

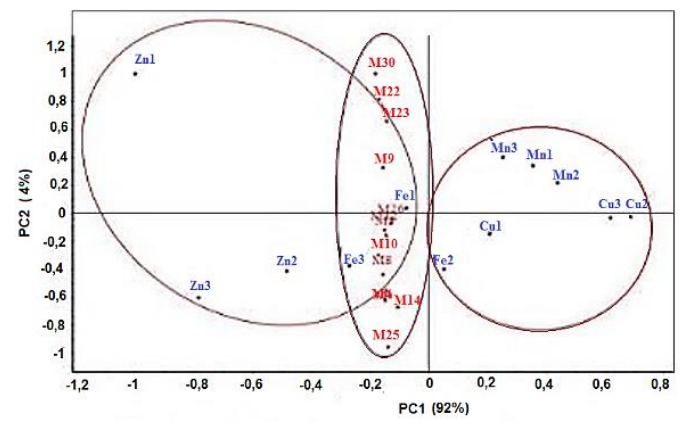

Figure 5. Biplot of PCA, PC1 (92\%) and PC2 (4\%), which explain the relationship between microelements in the 12 selected samples.

The lowest content of lead $(\mathrm{Pb})$ was presented by the sample of cocoa paste M15, variety CCN -51 from the sector of Pendencia with $0.20 \pm 0.02 \mathrm{ppm}$ and the highest content was presented by the dry fresh grain sample M15, from CCN-51 variety of the Pendency sector with $4.66 \pm$ $0.01 \mathrm{ppm}$. Bertoldi et al. (2016), have reported $\mathrm{Pb}$ contents in cocoa beans and derivatives, from different parts of the world with values between $0.0528-0.1881$ ppm, the Regulation (EU), (2015), has established limits in the content of $\mathrm{Pb}$ in various foods that varies between 0.01 $3.00 \mathrm{ppm}$; It was also indicated that lead could have serious harmful effects, such as neurotoxicity in young children, and cardiovascular effects and nephrotoxicity in adults. The results of $\mathrm{Pb}$ found, in some cases exceed these limits, but should be considered the amount of consumption made by each individual and it would be advisable to deepen the study of this metal, in other samples of cocoa beans and derivatives.

Figure 6 shows the PCA, for cadmium and its relation to the samples, PC1 explains $99 \%$ of the content of this metal in the samples and PC2 only 1\%. This indicates that samples of fresh dried grains M19, M18, M17, M29, M1, M2, M3, M10, M11 and M30, presented the highest cadmium contents 
(Cd1), varying between $0.59 \pm 0.03$ (M30) $1.21 \pm 0.02$ (M17) ppm and the lowest, 20 samples; varying between $0.05 \pm 0.01-0.34$ \pm 0.00 ppm; being sample M7, variety FC4 Pumahuasi sector which presented 0.34 ppm cadmium.

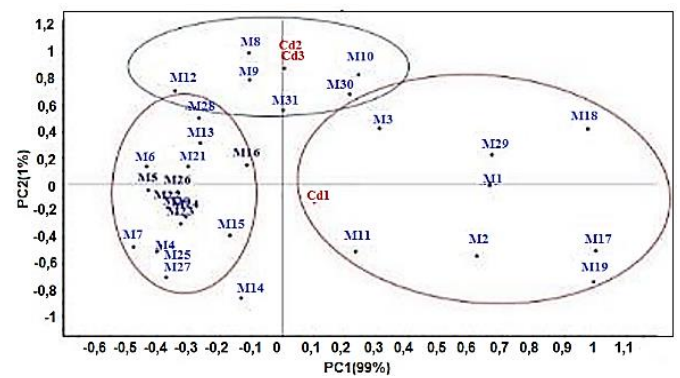

Figure 6. Biplot of PCA, PC1 (99\%) and PC2 (1\%), which explain the relationship between cadmium content $(\mathrm{Cd})$, and the samples.

Figure 7 shows the PCA, for lead and its relation to the samples, PC1 explains $70 \%$ of the content of this metal in the samples and PC2 $18 \%$. The biplot explains $88 \%$ of the variability of the responses, appreciating that there were three different groups, the samples of dry fresh cocoa beans, with the highest $\mathrm{Pb}$ content, varying between $3.44 \pm 0.05$ (M20) - $4.66 \pm 0.007$ (M15) ppm; the average content varying between $2.54 \pm$ 0.03 (M2) $-3.20 \pm 0.04$ (M9) ppm and the samples with the lowest contents of $\mathrm{Pb}$, samples M1 (1.28 $\pm 0.01 \mathrm{ppm})$, M21 (1.35 \pm $0.02 \mathrm{ppm})$ and M22 (1.33 $\pm 0.05 \mathrm{ppm})$.

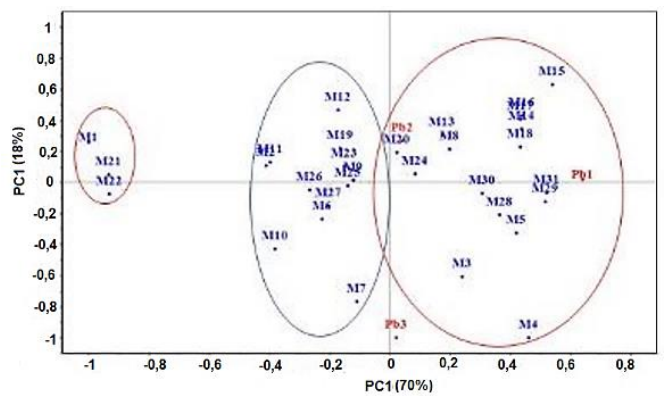

Figure 7. Biplot of PCA, PC1 (70\%) and PC2 (18\%), which explain the relationship between lead content $(\mathrm{Pb})$, and the samples.

3.5. Content of total polyphenols, anthocyanins and antioxidant capacity in fresh dried grains, dry fermented grains and cocoa paste

The content of total polyphenols (PPT) was higher in the fresh dry grain, sample M20, of the Common variety of the sector of Huayhuantillo, with $5.01 \pm 0.08 \mathrm{~g}$ AGE / 100 $\mathrm{g}$ of sample, and the lowest content was presented Sample M19, Criollo variety of Pendencia sector with $3.27 \pm 0.04 \mathrm{~g}$ AGE I $100 \mathrm{~g}$ of sample. The content of PPT decreased in dry fermented grains, with higher content in sample M15, variety $\mathrm{CCN}$ 51 from the sector of Pendencia with $3.30 \pm$ $0.02 \mathrm{~g} \mathrm{AGE} \mathrm{/} 100 \mathrm{~g}$ of sample, and the lowest content was presented by the shows M14 Common variety of the Pendent sector with $1.24 \pm 0.03 \mathrm{~g} \mathrm{AGE} \mathrm{/} 100 \mathrm{~g}$ of sample. The content of PPT, also decreased in samples of cocoa paste, sample M18, variety CCN-51 of the sector of Pendencia, presented $3.12 \pm 0.01 \mathrm{~g}$ AGE / $100 \mathrm{~g}$ of sample, and sample M30, variety Common of the Frontera sector presented $1.70 \pm$ $0.02 \mathrm{~g}$ AGE / $100 \mathrm{~g}$ of sample. Peláez et al. (2016), reported total polyphenols content in dry fresh cocoa beans and dry fermented grains, decreasing from $7.0-5.05 \pm 0.02 \mathrm{~g}$ AGE / $100 \mathrm{~g}$, in a fermentation system semimechanized

The content of anthocyanins (ANT) decreased, being higher in the dry fresh grain and lower in the pulp samples. The highest content of ANT in fresh dry grains was presented by sample M20, Common variety of the sector of Huayhuantillo with $44.88 \pm 0.51 \mathrm{mg}$ Cyanidin-3-glucoside I $100 \mathrm{~g}$ of sample, and the lowest content was presented by the sample M31, ICS-55 variety of the Frontera sector with $10.24 \pm$ 0.51 Cyanidin-3-glycoside / $100 \mathrm{~g}$ sample. The highest content of ANT in dried fermented grains was presented by sample M18, variety CCN-51 from the Pendencia sector with $30.34 \pm 0.68 \mathrm{mg}$ Cyanidin-3glucoside / $100 \mathrm{~g}$ of sample, and the lowest content was presented sample M3, variety CCN-51 from Pumahuasi sector with $2.45 \pm$ $0.19 \mathrm{mg}$ Cyanidin-3-glucoside / $100 \mathrm{~g}$ sample. The highest content of ANT in cocoa pastes was presented by sample M10, Criollo variety from the sector of José de Pucate with $15.37 \pm 0.33 \mathrm{mg}$ Cyanidin-3glucoside $/ 100 \mathrm{~g}$ of sample, and the lowest content was presented sample M23, Common variety of the Frontera sector with $3.12 \pm 0.19 \mathrm{mg}$ Cyanidin-3-glucoside $/ 100 \mathrm{~g}$ sample. Regarding the content of anthocyanins in cocoa beans (Zapata et al., 2013), they have reported variations between $0.16-0.027 \mathrm{~g}$ cyanidin-3-glucoside I $100 \mathrm{~g}$, for fermented and unfermented grains respectively.

The highest content of antioxidant capacity expressed as Trolox equivalents (TEAC) determined by ABTS test in dry fresh grain, was presented by sample M10, Criollo variety from the San Jose de Pucate sector with $591.50 \pm 3.76 \mu \mathrm{M}$ ET / g sample, and the lowest content was presented by sample M19, Criollo variety from the Pendencia sector with $293.31 \pm 2.99 \mu \mathrm{M}$ ET I g of sample. The highest content of TEAC 
determined by DPPH assay in fresh dry grains was presented by sample M10, Criollo variety from the San José de Pucate sector with $513.68 \pm 0.84 \mu \mathrm{M}$ ET / g sample and the lowest content was presented by the sample M19, Criollo variety of the Pendencia sector with $342.13 \pm 2.58 \mu \mathrm{M}$ ET I g of sample; Zapata et al. (2013), have reported antioxidant DPPH capacities, expressed in trolox equivalents, in various samples of unfermented and fermented cocoa beans, with values of $251.59 \pm 10.62$ - 464.64 $\pm 21.68 \mu \mathrm{M}$ ET / g, being greater in unfermented grain. The highest content of TEAC by ABTS test in dried fermented grains was presented by sample M28, ICS95 variety from the Frontera sector with $283.37 \pm 1.37 \mu \mathrm{M}$ ET / $\mathrm{g}$ sample, and the lowest content was presented by the sample M19, Criollo variety of the Pendency sector with $116.33 \pm 0.91 \mu \mathrm{M}$ ET / $\mathrm{g}$ of sample. Perea et al. (2009), have reported ABTS antioxidant capacities, expressed in Trolox equivalents, in samples of dry fermented grains and cocoa mass, with values of $270.11 \pm 82.40-361.45 \pm 44.68 \mu \mathrm{M}$ ET / g, with greater antioxidant capacity in dry fermented grains. The highest content of TEAC per DPPH test in dry fermented grains was presented by sample M12, variety $\mathrm{CCN}-51$ from the Mapresa sector with $137.43 \pm 0.32 \mu \mathrm{M}$ ET / g sample, and the lowest content was presented by the sample M16, VPA-2 of the Pendencia sector with $69.19 \pm 0.63 \mu \mathrm{M}$ ET / $\mathrm{g}$ of sample. The highest content of TEAC by ABTS test in cocoa paste was presented by sample M19, Criollo variety from the Pendencia sector with $412.34 \pm 2.26 \mu \mathrm{M}$ ET / g of sample, and the lowest content was presented by sample M18, variety CCN-51 of the Pendencia sector with $164.61 \pm 1.37 \mu \mathrm{M}$ ET / g of sample. The highest content of TEAC by DPPH assay in cocoa mass was presented by sample M29, variety $\mathrm{CCN}-51$ from the Mapresa sector with $233.85 \pm 1.48 \mu \mathrm{M}$ ET / g sample, and the lowest content was presented by sample M6, FC3 of the Pumahuasi sector with $91.05 \pm 0.42 \mu \mathrm{M}$ ET/g of sample.

The PCA score graphed of Figure 8 and the load graph of Figure 9, explain $99 \%$ of the response variability, with the formation of four groupings, from left to right; one formed in PC-1, by the variables of antioxidant capacity (ABTS1, DDPH1), of dry fresh cocoa beans samples, related to 10 samples, M10, M24, M25, M23, M26, M2, M15, M27, M1, and M22. In this group, sample M10, of dry fresh grain, presented the highest antioxidant capacity according to the radicals $A B T S 1$ and $D D P H 1$, with values of $591.50 \pm 3.76$ and $513.68 \pm 0.84$ $\mu \mathrm{M}$ ET / g, capacity which was decreasing according to the location of the samples to the right of the group. Group two, formed by the variables of antioxidant capacity (ABTS2, DPPH2), samples of dry fermented grains and antioxidant capacity (DPPH3,), samples of cocoa paste, related to 10 samples: M21, M5, M7, M11, M28, M6, M13, M4, M3 and M12. These samples presented intermediate values of antioxidant capacities, in relation to the indicated variables.

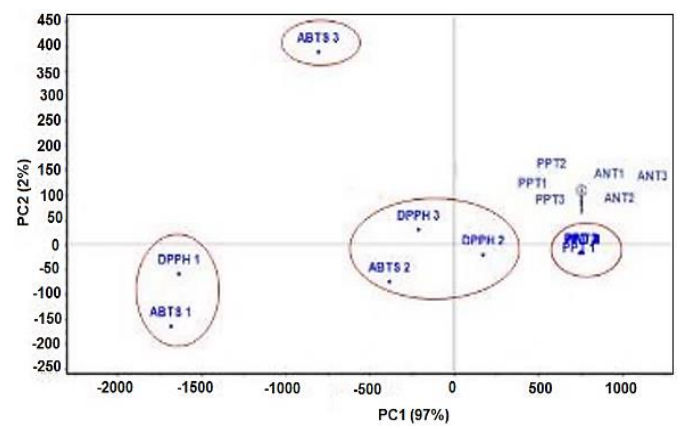

Figure 8. Graph of scores of the PCA, PC1 (97\%) and PC2 (2\%), which explain the relationship between the variables of antioxidant capacity, polyphenols and anthocyanins.

The three grouping, formed by the variables of the content of total polyphenols and anthocyanins (PPT1, PPT2, PPT3, ANT1, ANT2, ANT3), in the samples of dry fresh cocoa beans, dry fermented grains and in samples of cocoa paste, related to 5 samples: M29, M18, M30, M20 and M31. These samples showed the lowest antioxidant capacities, in the order from left to right, with values of ABTS between $244.18 \pm 2.61-327.71 \pm 1.50 \mu \mathrm{M}$ ET / $\mathrm{g}$ and DPPH between $126.04 \pm 0.32-362.66 \pm$ $0.84 \mu \mathrm{M}$ ET / g; with the characteristic that the samples of dry fresh grain presented the highest values and the dry fermented grains the lowest values.

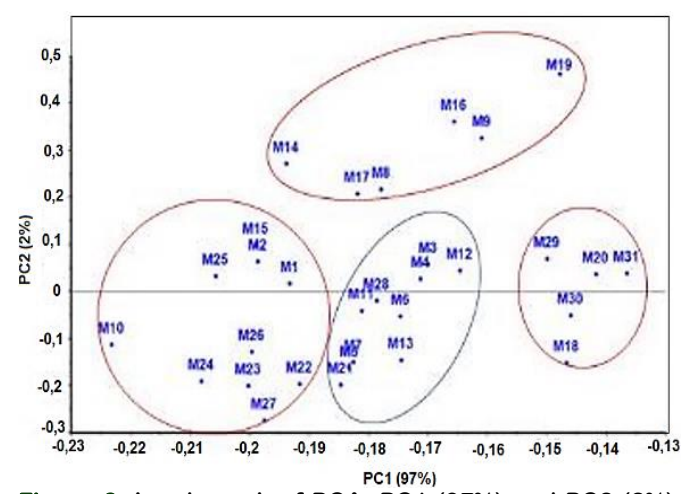

Figure 9. Load graph of PCA, PC1 (97\%) and PC2 (2\%), which correlates the samples and explains the affinity of characteristics among them, in the analysis of antioxidant capacity, polyphenols and anthocyanins. 
The cluster four, superior, formed in PC-2, by the variable of antioxidant capacity (ABTS3), in samples of cocoa paste, related to 6 samples: M19, M16, M9, M14, M8 and M7. In this group sample M19, of cocoa paste, presented the highest antioxidant capacity in function of the radical ABTS3, with the value of $412.34 \pm 2.26 \mu \mathrm{M}$ ET / g, capacity that was decreasing according to the location of the samples towards down the group.

\section{Conclusions}

The analysis of principal components (PCA) determined that calcium reached the highest content in dry fresh grain (M26), with $3.14 \%$. The highest content of potassium in the dry fresh grain corresponded to the sample M13, with $2.44 \%$. In the zinc content, in dry fresh grains, it was higher in samples M30, M22, M23 and M9; with $90.46 \pm 0.19 \mathrm{ppm}$, in M30. The copper content varied between $29.02 \pm$ $0.01-4.07 \pm 0.05 \mathrm{ppm}$, for the sample of dry fresh grain (M4) and cocoa mass (M3), respectively. The iron varied between 40.51 $\pm 0.01-14.46 \pm 0.01 \mathrm{ppm}$, for the dry fresh grain sample (M31) and for the dry fermented grain sample (M3), respectively. Twenty-five samples had contents less than $0.61 \pm 0.01 \mathrm{ppm}$ of cadmium; value that was found below the maximum content in international standards and regulations. Lead was found in higher content in dried fermented grain (M20) with $3.44 \pm 0.05$ ppm and the lowest in (M22) with $1.33 \pm 0.05$ $\mathrm{ppm}$. The lowest $\mathrm{Pb}$ content was presented by cocoa paste (M15), with $0.20 \pm 0.02 \mathrm{ppm}$. The highest content of total polyphenols was found in fresh dry grain (M20), common variety of the Huayhuantillo sector with $5.01 \pm 0.08 \mathrm{~g} \mathrm{AGE} / 100 \mathrm{~g}$ of sample; the lowest content was presented by the cocoa paste (M30), Common variety of the Frontera sector, with $1.70 \pm 0.02 \mathrm{~g} \mathrm{AGE} \mathrm{I}$ $100 \mathrm{~g}$ of sample. The content of anthocyanins was higher in the dry fresh grain samples and lower in the samples of cocoa paste; the largest in the sample (M20), Common variety of the sector of Huayhuantillo with $44.88 \pm 0.51 \mathrm{mg}$ Cyanidin-3-glycoside / $100 \mathrm{~g}$ of sample, and the lowest in the sample (M31), ICS-55 variety of the sector of Frontera with 10.24 \pm 0.51 Cyanidin-3-Glucoside / $100 \mathrm{~g}$ of sample. The highest antioxidant capacity was presented by the sample (M10), of dry fresh grain, based on the ABTS and DDPH radicals, with values of $591.50 \pm 3.76$ and $513.68 \pm 0.84 \mu M$ ET / g. Cocoa paste showed the highest antioxidant capacity, sample (M19), based on the ABTS radical, with $412.34 \pm 2.26 \mu \mathrm{M} \mathrm{ET/g}$.

\section{Acknowledgements}

The authors would like to thank Innovate Peru and the Ministry of Production of Peru for research funding.

\section{ORCID}

P. Peláez (D) https://orcid.org/0000-0001-9127-2068

\section{References}

APCACAO. 2015. Asociación Peruana de Productores de Cacao, Perú. Pp. 3-9.

Bakircioglu, D.; Topraksever, N.; Yurtsever, S.; Kizildere, M.; Kurtulus, Y. B. 2018. Investigation of macro, micro and toxic element concentrations of milk and fermented milks products by using an inductively coupled plasma optical emission spectrometer, to improve food safety in Turkey. Microchemical Journal 136: 133-138.

Barrueta, M. 2013. Guía de métodos de detección y análisis de cadmio en cacao. Perú. Pp 1-45.

Bernardo, C.O.; Ascheri, J.L.R.; Chávez, D.W. H.; Carvalho, C.W.P. 2018. Ultrasound Assisted Extraction of Yam (Dioscorea bulbífera) Starch: Effect on Morphology and Functional Properties. Starch - Stärke 70: 5-6.

Bertoldi, D.; Barbero, A.; Camin, F.; Caligiani, A.; Larcher, R. 2016. Multielemental fingerprinting and geographic traceability of Theobroma cacao beans and cocoa products. Food Control 65: 46-53.

Bilandžić, N.; Sedak, M.; Đokić, M.; Božić, Đ.; Vrbić, A. 2015. Content of macro- and microelements and evaluation of the intake of different dairy products consumed in Croatia. Journal of Food Composition and Analysis 40: 143-147.

Brand-Williams, W.; Cuvelier, M.E.; Berset, C. 1995. Use of a free radical method to evaluate antioxidant activity. LWT - Food Science and Technology 28(1): 25-30.

Calderón, F.; Pavlova, M. 2004. Metodologías del análisis foliar. Calderón Laboratorios Ltda., Bogotá D.C., Colombia SA. Disponible en: http://www.drcalderonlabs.com/Metodos/Ana lisis_Foliar/Metodos_Analisis_Foliares.htm

Djikeng, F.T.; Teyomnou, W.T.; Tenyang, N.; Tiencheu, B.: Morfor, A.T.; Touko, B.A.H.; ... Womeni, H.M. 2018. Effect of traditional and oven roasting on the physicochemical properties of fermented cocoa beans. Heliyon 4(2): e00533.

Esbensen, K.; Swarbrick, B. 2017. Multivariate Data Analysis. $6^{\text {th }}$ Edition. Copenhagen, Sydney, Oslo, EEUU. Pp. 1-452.

Fartusie, F.: Mohssan, S. 2017. Essential Trace Elements and Their Vital Roles in Human Body. Indian Journal of Advances in Chemical Science India 5(3): 127-136.

Gharibzahedi, S.; Jafari, S. 2017. The importance of minerals in human nutrition: Bioavailability, food fortification, processing effects and 
nanoencapsulation. Trends in Food Science \& Technology, Iran 62: 119-132.

IMCO, 2015. Principales países productores de cacao. Instituto Mexicano para la Coperatividad A.C. México. Available in: https://imco.org.mx/home/

Lewis, C.; Lennon, A.; Eudoxie, G.; Umaharan, P. 2018. Genetic variation in bioaccumulation and partitioning of cadmium in Theobroma cacao L. Science of The Total Environment 640-641: 696-703.

Li, J.; Ma, G.; Ma, L.; Bao, X.; Li, L.; Zhao, Q.; Wang, Y. 2018. Multivariate Analysis of Fruit Antioxidant Activities of Blackberry Treated with 1-Methylcyclopropene or Vacuum Precooling. International Journal of Analytical Chemistry Article ID 2416461: 1-5.

Martínez, C.; Nieves, S.; Arévalo, N.; Verde, K.; Rivas, M.; Oranday, M.; Cárdenas, A.; Núñez, M.; Morales, M. 2011. Antocianinas y actividad anti radicales libres de rubus adenotrichus schltdl (zarzamora). Revista mexicana de ciencias farmacéuticas, México 42(4): 66-71.

Mesa, L.; Gozá, O.; Uranga, M.; Toledo, A.; Gálvez Y. 2018. Aplicación del Análisis de Componentes Principales en el proceso de fermentación de un anticuerpo monoclonal. Vaccimonitor. Cuba 27(1): 8-15.

Miller, N. 1993. A novel method for measuring antioxidant capacity and its application to monitoring the antioxidant status in premature neonates. Clinical Science 84(4): 407-412.

Ovaco, V.; Pineda, LL. 2011. Los residuos de cacao (Teobroma cacao L) como fuente alternativa de antioxidante. Tesis ing. Industrias Agropecuarias. Universidad Católica de Loja. Loja. Ecuador. 42 pp.

Peláez, P.: Guerra, S.; Contreras, D. 2016. Changes in physical and chemical characteristics of fermented cocoa (Theobroma cacao) beans with manual and semi- mechanized transfer, between fermen-tation boxes. Scientia Agropecuaria 07(02): 111119.

Perea, J.; Cadena, T.; Herrera, J. 2009. El cacao y sus productos como fuente de antioxidantes: Efecto del procesamiento. Salud 41(2): 128-134.

Reglamento (UE). 2014. Reglamento (UE) No 488, que modifica el Reglamento (CE) no $1881 / 2006$ por lo que respecta al contenido máximo de cadmio en los productos alimenticios. $5 \mathrm{pp}$.

Reglamento (UE). 2015. Reglamento (UE) 2015/1005 de la comisión, que modifica el Reglamento (CE) no 1881/2006 por lo que respecta al contenido máximo de plomo en determinados productos alimenticios. $5 \mathrm{pp}$.

Romero-Estévez, D.; Yánez-Jácome, G.S.; Simbaña-Farinango, K.; Navarrete, H., 2019. Content and the relationship between cadmium, nickel, and lead concentrations in Ecuadorian cocoa beans from nine provinces. Food Control 106: 106750.

Singleton, V.; Rossi, J. 1965. Colorimetry of total phenolics with phosphomolybdic. American Journal of Enology and Viticulture (16): 144158.

Studziński, T.; Matras, J.; Grela, E.R.; Piedra, J. L.V.; Truchliński, J.; Tatara, M.R. 2006. Chapter 16 Minerals: functions, requirements, excessive intake and toxicity. Biology of Nutrition in Growing Animals. Poland. Pp. 467-509.

Varian, H. 1989. Analytical methods: Flame atomic absorption spectrometry. Publication $\mathrm{N}^{\circ}$ 85-100009-00 Australia, Mulgrave, Victoria: Varian Australia Pty Ltd.

Zapata, S.; Tamayo, A.; Alberto, B. 2013. Efecto de la fermentación sobre la actividad antioxidante de diferentes clones de cacao colombiano. Revista cubana de planta medicinales 18(3): 391-404. 